\title{
Tourist Activity of Senior Citizens (60+) Residing in Urban and Rural Areas
}
Authors' contribution:
A) conception and design of the study
B) acquisition of data
C) analysis and interpretation of data
D) manuscript preparation
E) obtaining funding

\author{
Aneta Omelan ${ }^{\mathrm{A}-\mathrm{E}}$, Robert Podstawski ${ }^{\mathrm{A}-\mathrm{E}}$, \\ Marek Raczkowski ${ }^{\mathrm{C}}$ \\ University of Warmia and Mazury in Olsztyn, Poland
}

\section{ABSTRACT}

The objective of this study was to analyze the influence of place of permanent residence (urban or rural) on the tourist activity of senior citizens $(60+)$ of different socioeconomic statuses. The study involved 380 senior citizens (305 female and 75 male) aged 60 years and older who were permanent residents of the region of Warmia and Mazury, Poland. In this group, 244 subjects resided in urban areas and 136 participants were rural dwellers. The respondents were asked to complete a questionnaire regarding their socioeconomic status (place of permanent residence, age, gender, educational attainment, financial status, membership in senior organizations, marital status, and professional activity) and tourist activity. A significance test of two structure coefficients $(\alpha=0.05)$ was applied. Factors such as gender, professional activity, and marital status were not related with the travel propensity of seniors from different groups (urban and rural), but were significant when rural residents were compared with urban dwellers. Seniors residing in urban areas of Warmia and Mazury, Poland, were significantly more likely to travel for leisure than those residing in rural areas. The tourist activity of seniors decreased significantly $(\mathrm{p}<0.05)$ with the age $(60-74$ years $)$ and financial status of rural residents. The travel propensity of elderly people increased significantly $(\mathrm{p}<0.05)$ with educational attainment and membership in senior organizations. The study revealed considerable differences in the socioeconomic status and social characteristics of seniors residing in rural and urban areas, and those variations significantly influenced their propensity for travel: urban residents traveled more frequently than rural residents. It can be concluded that place of residence was a crucial factor determining the tourist behavior of senior citizens, and urban dwellers were more likely to travel.

KEYWORDS

senior citizens, tourist activity, urban area, rural area, socioeconomic factors

\section{Introduction}

The problem of an aging population and associated concerns are increasingly often addressed by researchers from various fields of science. The number of senior citizens continues to grow and life expectancy is on the rise, yet population growth has been visibly stilted. Since 1950, the number of people aged $65+$ has tripled from 130 million to 419 million, and in 2000, seniors accounted for approximately $6.9 \%$ of the global population (Kinsella, \& Velkoff, 2001). According to estimates, the population of people aged 60 years and over will double from 841 million in 2013 to nearly one billion in 2050 (United Nations, 2013). Seniors also account for a large part of the Polish population: 7,361,400 in total, with 4,949,800 of these being elderly pensioners (Polish Social Insurance Institution, 2012). Nearly 520,000 seniors are 85 and older. According to 
the Polish Central Statistical Office (PCSO, 2012), the number of citizens aged 85+ will reach 800,000 in 20 years, whereas the middle-aged population will be reduced by a third (Bunda, \& Walewski, 2012). Population aging will affect all areas of life, including the housing market, market services, and the Internet (Benowa, Grundy, \& Plobidis 2014; Jang, \& Wu 2006).

Aging is a natural part of life, and senior citizens should enjoy good physical and mental health in their autumn years. The well-being of the elderly can be improved by promoting the concept of positive ageing, i.e., low levels of disability, maintenance of physical and mental autonomy, reinforcement of positive attitudes towards life, and active involvement in social affairs (Straight et al., 2012; Watt, Carson, Lawron, Patel, \& Ebrahim 2009). Positive aging applies to various areas of life, and physical functioning plays a very important role because it prolongs autonomy, boosts mobility, and increases overall quality of life (Henwood, Riek, \& Taaffe, 2008). Tourism offers various options for increasing mobility in seniors. Together with recreation, tourism is a vital contributor to quality of life in highly developed societies of the twenty-first century (Esichaikul, 2012; Hu, Wang, \& Wang, 2013; Jang, \& Wu, 2006). Tourism involves a set of behaviors manifested by an active attitude towards leisure travel. Tourist activities can help seniors overcome mobility issues, prevent social isolation, contribute to the maintenance of health, physical fitness, and independence, and enable the elderly to rediscover the meaning of life (Bieger, \& Laesser, 2005). Tourism generally involves group activities, which encourage seniors to venture out into the world and develop positive attitudes towards life. The elderly spend most of their time at home, often in isolation, which increases the risk of depression; travel opportunities enable the elderly to leave their homes (Dann, 1981). Tourism can compensate for the loss of social functions, and it enables seniors to appreciate the positive aspects of retirement (Shankar, McMunn, $\&$ Steptoe 2010). Nonetheless, the tourism industry mostly targets younger consumers and has far less to offer clients from the 50+ age group (Szmigin, \& Carrigan, 2000). This is a short-sighted strategy because many senior citizens are keen on exploring the world and participating in new activities for as long as they are in good physical and mental health (Kazemina, Del Chiappa, \& Jafari, 2015; Paterson, 2006). According to population growth projects, seniors will soon constitute the largest segment on the global tourist market (Chesworth, 2006; Huang, \& Tsai, 2003; Nickerson, 2000; Reece, 2004).

According to Romsa and Blenman (1989), the vacation behavior of senior citizens is determined mostly by their socioeconomic status, including their age, gender, and financial standing. Sauran (1978) and Jang and $\mathrm{Wu}$ (2006) have identified other socioeconomic factors that influence seniors' involvement in tourism, including educational attainment, professional activity, and place of residence. Rosenbloom and Waldorf (2001) relied on the results of the 1995 National Personal Transport Survey to demonstrate the effect of relative location (urban or suburban) on public transport among older adults. The relationships between tourist activity and various socioeconomic factors have also been described by other authors (Cha, McLeary, \& Uysal, 1995; Gokovani, Bahar, \& Kozak, 2007; Jang, Bai, Hong, \& O’Leary, 2004; Nicolau, \& Más, 2005). Blazey (1987) observed that health status is a critical consideration behind seniors' motivation and willingness to participate in travel activities. Seniors are often confronted with life-stage events such as retirement and the deteriorating health of their spouse and friends (Jang, \& Wu, 2006). Life transitions often trigger feelings of uncertainty, fear, depression, and inadequacy (Mroczek, \& Kolarz, 1998). Many seniors take up travel as an escape from disillusionment and distress. Research investigating the impact and effects of sociodemographic variables (age, gender, economic status, and health) on senior citizens' motivation to travel could deliver very interesting results. According to Nyaupane and Andereck (2008), senior tourists' preferences and involvement are determined mainly by family size, marital status, and type of activity. There are also structural constraints that determine senior citizens' leisure preferences and prevent the elderly from actively participating in tourist activities, including lack of time, information, money, opportunities, transportation, and facilities (Hawkins, Peng, Hsieh, \& Eklund, 1999). In itself, the promotion of tourism as an attractive leisure activity is unlikely to garner participation from senior citizens. Effective senior tourism programs should rely on the results of surveys identifying the key factors in elderly citizens' decision to take up travel. This is particularly important in communities that remain outside the reach of senior organizations and associations (unaffiliated seniors and rural residents). 
Senior tourism has been extensively researched in Poland, but most studies focus on members of senior organizations, particularly students of the Universities of the Third Age (UTA), who eagerly participate in surveys. Those respondent groups are well organized and highly motivated to engage in various types of activities (Gołdys, Krzyżanowska, Ostrowski, \& Stec, 2012). Most of them involve urban residents. The tourist activities of unaffiliated seniors and elderly inhabitants of rural areas situated more than $40 \mathrm{~km}$ from a town or city who rarely visit cities and are characterized by lower socioeconomic status remain insufficiently researched. An analysis of senior tourist behaviors based on selected environmental factors would deliver valuable results and fill the knowledge gap related to this social group. The aim of this study was to determine whether select socioeconomic factors (independent variables: place of residence, gender, age, educational attainment, financial status, membership in senior organizations, marital status, and professional activity) influence the travel propensity of senior citizens $(60+)$. The main objective was pursued by determining whether senior citizens in the Polish region of Warmia and Mazury pursue tourist activities and whether place of permanent residence significantly influences the tourist activity of senior citizens of different socioeconomic statuses.

\section{Materials and methods}

\section{Participants}

For the purpose of this study, it was necessary to define the concept of a senior citizen. The aging process ends at death, whereas the beginning of the aging process is more difficult to define. Many experts define

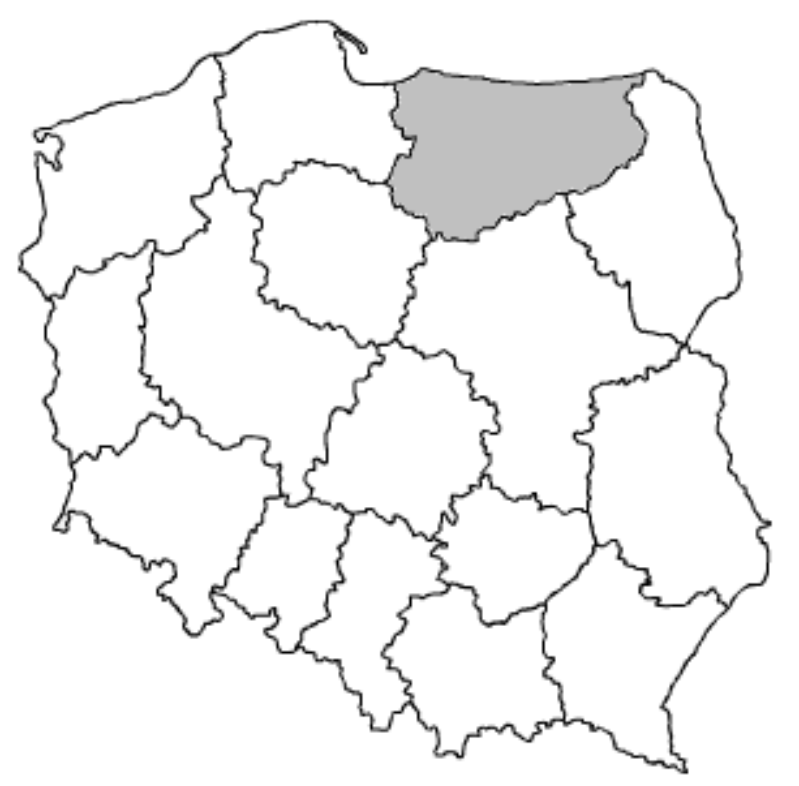

Figure 1. A map of Poland identifying the region of Warmia and Mazury, where the study was conducted Source: own study. senior citizens as persons who are 65 years old or older (Freud, 1997; Gorman, 1999; Roebuck, 1979; Thane ,1989). Based on the existing research, the World Health Organization identified the following sub-groups of senior citizens (WHO, 2015; Yasamy, Dua, Harper, \& Saxena, 2015):

- young-old: aged 60 to 74 years

- old-old: aged 75 to 89 years

- oldest-old: aged 90+

The above classification system was used in this study. The study involved 380 senior citizens (305 female and 75 male) aged 60 years and older who permanently resided in the region of Warmia and Mazury, Poland (Fig. 1).

The region of Warmia and Mazury was chosen for the study because it is the largest Polish region with a predominance of agriculture and tourism. The researchers aimed to survey elderly citizens residing in a typically rural setting and to compare the results with the answers provided by urban dwellers. The respondents are described in Table 1.

The vast majority of respondents (87.89\%) belonged to the young-old group of seniors aged 60-74. This group consisted of 214 urban residents and 120 rural residents. The remaining subjects were aged 75-89 and were part of the old-old group; 30 of these subjects resided in urban areas and 16 resided in rural areas. The distribution of respondents according to gender was similar in both age groups ( $\mathrm{p}=0.8771$ ). Women accounted for $80.26 \%$ of all surveyed subjects. Clear differences were observed between genders with regard to their place of residence. More females were among the urban residents (87.77\%) than the rural residents (66.91\%). Urban areas had a significantly higher population of female seniors than rural locations $(\mathrm{p}=0.0000)$. Half of the respondents (50\%) had acquired secondary education, and $26.58 \%$ were university graduates. Seniors residing in rural areas were significantly less educated than their urban counterparts. From the rural 
respondents, $29.41 \%$ had only a primary school education, whereas only $2.05 \%$ of urban dwellers had stopped their education at the primary school level. Respondents with secondary and higher education were represented by $29.10 \%$ and $62.70 \%$ of the urban population and $22.06 \%$ and $27.21 \%$ of the rural population, respectively. Significant differences between rural and urban residents were not observed with respect to university graduates $(\mathrm{p}=0.1364)$, but they were noted among respondents with secondary, vocational, and primary education ( $\mathrm{p}=0.0000$ in all cases).

Table 1. Socioeconomic status of senior respondents

\begin{tabular}{|c|c|c|c|c|c|c|c|c|}
\hline \multicolumn{6}{|c|}{ Respondents } & \multirow{2}{*}{\multicolumn{2}{|c|}{$\begin{array}{c}\text { Total } \\
\mathbf{N}=\mathbf{3 8 0}\end{array}$}} & \multirow{3}{*}{$\mathbf{p}$} \\
\hline \multirow[t]{2}{*}{ Factors } & \multirow[t]{2}{*}{ Categories } & \multicolumn{2}{|c|}{$\begin{array}{c}\text { Urban }(C) \\
\mathrm{N}=\mathbf{2 4 4} \\
\end{array}$} & \multicolumn{2}{|c|}{$\begin{array}{c}\text { Rural (D) } \\
\mathrm{N}=136\end{array}$} & & & \\
\hline & & $\mathbf{N}$ & $\%$ & $\mathbf{N}$ & $\%$ & $\mathbf{N}$ & $\%$ & \\
\hline \multirow{2}{*}{ Age } & $60-74$ years $(A)$ & 214 & 87.7 & 120 & 88.24 & 334 & 87.89 & $\begin{array}{c}\mathrm{AC}-\mathrm{AD} \\
\mathrm{p}=0.8771\end{array}$ \\
\hline & $75-84$ years $(\mathrm{B})$ & 30 & 12.3 & 16 & 11.76 & 46 & 12.11 & $\begin{array}{c}\text { BC-BD } \\
\mathrm{p}=0.8771\end{array}$ \\
\hline \multirow{2}{*}{ Gender } & Female (A) & 214 & 87.7 & 91 & 66.91 & 305 & 80.26 & $\begin{array}{c}\text { AC-AD } \\
p=0.0000\end{array}$ \\
\hline & Male (B) & 30 & 12.3 & 45 & 33.09 & 75 & 19.74 & $\begin{array}{c}\text { BC-BD } \\
p=0.0000\end{array}$ \\
\hline \multirow{4}{*}{$\begin{array}{l}\text { Educational } \\
\text { attainment }\end{array}$} & Higher (A) & 71 & 29.10 & 30 & 22.06 & 101 & 26.58 & $\begin{array}{c}\text { AC-AD } \\
p=0.1364\end{array}$ \\
\hline & Secondary (B) & 153 & 62.70 & 37 & 27.21 & 190 & 50.00 & $\begin{array}{c}\text { BC-BD } \\
p=0.0000\end{array}$ \\
\hline & Vocational (E) & 15 & 6.15 & 29 & 21.32 & 44 & 11.58 & $\begin{array}{c}\text { EC-ED } \\
p=0.0000\end{array}$ \\
\hline & Primary $(F)$ & 5 & 2.05 & 40 & 29.41 & 45 & 11.84 & $\begin{array}{c}\text { FC-FD } \\
p=0.0000\end{array}$ \\
\hline \multirow{4}{*}{$\begin{array}{c}\text { Financial } \\
\text { status }\end{array}$} & Very good (A) & 13 & 5.33 & 5 & 3.68 & 18 & 4.74 & $\begin{array}{c}\text { AC-AD } \\
\mathrm{p}=0.4680\end{array}$ \\
\hline & Good (B) & 110 & 45.08 & 58 & 42.65 & 168 & 44.21 & $\begin{array}{c}\text { BC-BD } \\
p=0.6475\end{array}$ \\
\hline & Average (E) & 119 & 48.77 & 68 & 50.00 & 187 & 49.21 & $\begin{array}{c}\text { EC-ED } \\
\mathrm{p}=0.8182\end{array}$ \\
\hline & Low $(F)$ & 2 & 0.82 & 5 & 3.68 & 7 & 1.84 & $\begin{array}{c}\text { FC-FD } \\
p=0.0469\end{array}$ \\
\hline \multirow{2}{*}{$\begin{array}{c}\text { Senior } \\
\text { organization }\end{array}$} & Member (A) & 163 & 66.80 & 30 & 22.06 & 193 & 50.79 & $\begin{array}{c}\text { AC-AD } \\
p=0.0000\end{array}$ \\
\hline & $\begin{array}{c}\text { Not a member } \\
\text { (B) }\end{array}$ & 81 & 33.20 & 106 & 77.94 & 187 & 49.21 & $\begin{array}{c}\text { BC-BD } \\
p=0.0000\end{array}$ \\
\hline \multirow{2}{*}{$\begin{array}{l}\text { Marital } \\
\text { status }\end{array}$} & Married (A) & 127 & 52.05 & 104 & 76.47 & 231 & 60.79 & $\begin{array}{c}\text { AC-AD } \\
p=0.0000\end{array}$ \\
\hline & Unmarried (B) & 117 & 47.95 & 32 & 23.53 & 149 & 39.21 & $\begin{array}{r}\text { BC-BD } \\
\mathbf{p}=\mathbf{0 . 0 0 0 0}\end{array}$ \\
\hline \multirow{2}{*}{$\begin{array}{c}\text { Professional } \\
\text { activity }\end{array}$} & Active (A) & 23 & 9.43 & 26 & 19.12 & 49 & 12.89 & $\begin{array}{c}\text { AC-AD } \\
p=0.0069\end{array}$ \\
\hline & Not active (B) & 221 & 90.57 & 110 & 80.88 & 331 & 87.11 & $\begin{array}{c}\text { BC-BD } \\
p=0.0069\end{array}$ \\
\hline
\end{tabular}

Notes: - $(p)$ - probability that the calculated chi-square value will be exceeded, significant differences are marked in bold.

Source: own study.

Nearly half of the surveyed subjects (49.21\%) evaluated their financial status as average, and $44.21 \%$ reported it to be good. The percentage of respondents who enjoyed a high financial standing was $4.74 \%$, and only $1.84 \%$ described their financial status as low. No significant differences in financial status were observed between rural and urban dwellers. A similar distribution of respondents (with regard to gender, age, education, 
and financial status) was reported by Jang and $\mathrm{Wu}$ (2006), who analyzed the tourist motivations of seniors in Taiwan. A total of $66.8 \%$ of urban inhabitants were members of community organizations, whereas only $22.06 \%$ of rural dwellers claimed to be actively involved in senior or community clubs. In this respect, the distribution of respondents varied between groups $(\mathrm{p}=0.0000)$. More than half of the polled subjects $(60.79 \%)$ were married, and the married population was significantly higher in rural $(76.47 \%)$ than in urban $(52.05 \%)$ areas $(\mathrm{p}=0.0000)$. Professionally active seniors accounted for $12.89 \%$ of the surveyed population, and this group of seniors was larger in rural areas, where $19.12 \%$ declared to be employed, in contrast to only $9.43 \%$ in cities. The distribution of professionally active seniors varied between groups at $\mathrm{p}=0.0069$ (Table 1 ).

\section{Procedures}

The study was conducted upon the approval of the Bioethical Committee at the University of Warmia and Mazury in Olsztyn. All participants agreed to participate in the study and signed informed consent forms.

\section{Data collection tool}

The study was carried out in the first months of 2015 in the Region of Warmia and Mazury, Poland. The respondents were aged 60 years and older. A detailed map of the analyzed region was developed to select locations that would be most conducive to the study. The researchers then solicited the support of municipal offices in contacting local residents aged 60 years and older. Many seniors could not be contacted, and some residents (66 women and 37 men) refused to participate in the survey.

The researchers designed a questionnaire containing nine closed-ended questions. Eight questions concerned the respondents' socioeconomic status, and in one question, the subjects were asked to indicate whether they traveled as tourists. The researchers contacted all respondents in person. Senior citizens aged 60+ are difficult to contact by telephone or e-mail, and they are rather uncooperative and reluctant respondents. Communication was relatively easily established with urban residents, but researchers found it much more difficult to obtain information from seniors residing in rural areas.

The Norfolk Planning Department and the Institute of Geography and Spatial Organization of the Polish Academy of Sciences define rural areas as territories situated 5 miles $(8 \mathrm{~km})$ from a town with a population of 20,000 and 10 miles $(16 \mathrm{~km}$ ) from a town with a population of 10,000 (Bański, 2014; Bański, \& Wesołowska, 2012). For the needs of this study, however, rural residents were defined as inhabitants of villages situated at least $40 \mathrm{~km}$ from the nearest town. This choice was made due to the progression of urban sprawl in Poland in the past two decades. Urban dwellers move to rural locations without giving up their city jobs or their urban lifestyle and, as a result, local villages become urbanized residential districts rather than true rural communities. The researchers attempted to reach seniors who had been living and working in a traditional rural setting, mostly in agriculture, throughout their lives, without any connections to the city. The social, economic, and cultural fabric of a traditionally rural community differs considerably from that of an urban area. The researchers succeeded in contacting members of such traditional rural communities. Some villages were far removed from main roads, many did not have hard-top roads, and the researchers often reached their destinations by foot or bicycle. In addition to logistic complications, the researchers also had to overcome the respondents' mental barriers. Village dwellers were reluctant to cooperate, and verbal communication was difficult with some seniors.

Senior citizens residing in urban areas were much easier to contact. Many of them were members of formal and informal groups and were socially active and curious about the world. For this reason, they displayed much more open attitudes and were more willing to participate in the survey. 


\section{Statistical analysis}

The results were processed in the Statistica v. 12 program with the use of the descriptive statistics module ( $\mathrm{N}$ and \%) and a significance test for two structure coefficients at a significance level of $\alpha=0.05$. The computed probability values denote an absence of statistically significant differences at $p \geq \alpha$ or the presence of statistically significant differences at $\mathrm{p}<\alpha$ (Rabiej, 2012).

\section{Results}

The results of the study illustrating differences in the tourist activity of senior citizens residing in urban and rural areas are presented in Table 2. The effect of respondents' (urban and rural residents) socioeconomic status (including gender, age, educational attainment, financial status, marital status, professional activity, and membership organizations) on their tourist behavior is presented in Table 3.

Table 2. Seniors' place of permanent residence and tourist activity

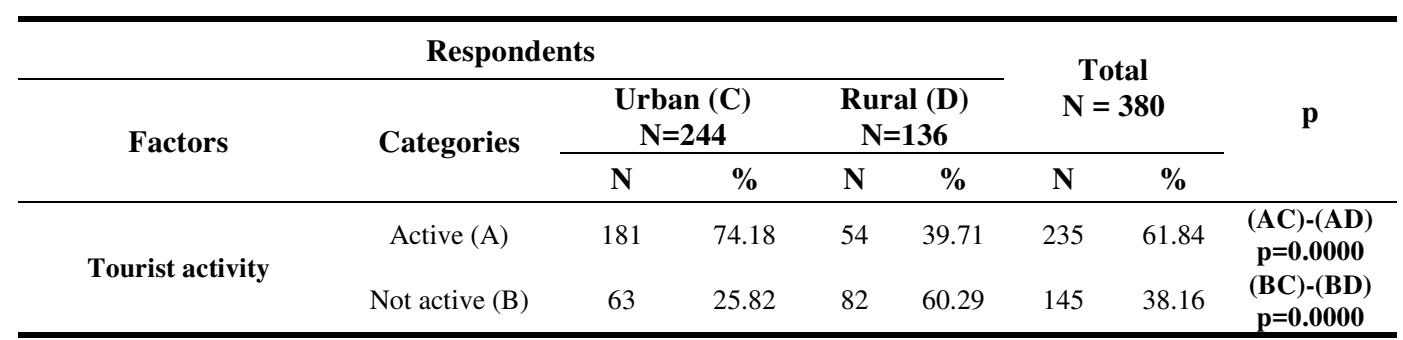

Notes: - $(p)$ - probability that the calculated chi-square value will be exceeded, significant differences are denoted in bold.

Source: own study.

Most of the surveyed seniors (61.84\%) claimed to travel for leisure. The population of active tourists was significantly larger $(\mathrm{p}=0.0000)$ in urban areas $(74.18 \%)$ than in rural locations $(39.71 \%)$. A statistical analysis of structure coefficients indicates that place of permanent residence significantly influences the travel propensity of seniors, and that urban residents are much more likely to travel for leisure. For this reason, the relationships between place of residence and the tourist behavior of respondents were processed in view of selected socioeconomic characteristics, including gender, age, educational attainment, financial status, membership in senior organizations, and professional activity.

Significantly more urban residents $(\mathrm{p}=0.0000)$, both female $(75.7 \%)$ and male $(63.33 \%)$, were active tourists than their rural counterparts (female $-40.66 \%$, male $-37.78 \%$ ). In spite of this, no relationships between gender and tourist behavior were determined separately for rural or urban residents. Similar results were noted in groups of seniors aged 60-74 years $(\mathrm{p}=0.000)$ and $75-84$ years $(\mathrm{p}=0.0400)$, while urban residents from both age groups were more likely to travel for leisure than rural dwellers. An analysis of relationships between age and tourist behavior revealed significant differences $(p=0.0192)$ among urban residents, whereas the data were similarly distributed in both age groups of rural residents $(\mathrm{p}=0.2005)$.

No significant differences in the level of tourist activity were observed among university graduates $(\mathrm{p}=0.0675)$ and respondents with vocational education $(\mathrm{p}=0.7637)$, regardless of their place of residence. Respondents with higher education were the most traveled group, whereas respondents with vocational education were the least traveled group in both urban and rural areas. Statistically significant differences were noted among respondents with secondary and primary school education $(\mathrm{p}=0.0008$ and $\mathrm{p}=0.0177$, respectively). In the group of seniors residing in urban areas, university and secondary school graduates traveled more than rural residents with vocational education $(\mathrm{p}=0.0001$ and $\mathrm{p}=0.0008$, respectively). In the group of rural residents, respondents with secondary education were more likely to travel for leisure than 
subjects with primary education $(\mathrm{p}=0.0030)$, whereas respondents with higher education were characterized by a higher propensity for travel than subjects with vocational $(\mathrm{p}=0.0271)$ and primary education $(\mathrm{p}=0.0291)$.

Table 3. Tourist activity and socioeconomic status of seniors residing in urban and rural areas

\begin{tabular}{|c|c|c|c|c|c|c|c|c|c|c|c|}
\hline \multirow{4}{*}{ Factors } & \multirow{4}{*}{ Categories } & \multicolumn{8}{|c|}{ Tourist behavior } & \multirow{4}{*}{$\begin{array}{c}p \\
\text { Urban-Rural }\end{array}$} & \multirow{4}{*}{$p$} \\
\hline & & \multicolumn{4}{|c|}{ Urban } & \multicolumn{4}{|c|}{ Rural } & & \\
\hline & & \multicolumn{2}{|c|}{$\begin{array}{l}\text { Active } \\
\text { (C) }\end{array}$} & \multicolumn{2}{|c|}{$\begin{array}{l}\text { Not active } \\
\text { (D) }\end{array}$} & \multicolumn{2}{|c|}{$\begin{array}{c}\text { Active } \\
\text { (E) }\end{array}$} & \multicolumn{2}{|c|}{$\begin{array}{l}\text { Not active } \\
\text { (F) }\end{array}$} & & \\
\hline & & $\mathrm{N}$ & $\%$ & $\mathrm{~N}$ & $\%$ & $\mathrm{~N}$ & $\%$ & $\mathrm{~N}$ & $\%$ & & \\
\hline \multirow{2}{*}{ Gender } & Female (A) & 162 & 75.70 & 52 & 24.30 & 37 & 40.66 & 54 & 59.34 & AC-AE $p=0.0000$ & AC-BC $p=0.1471$ \\
\hline & Male (B) & 20 & 63.33 & 10 & 36.67 & 17 & 37.78 & 28 & 62.22 & BC-BE $p=0.0000$ & AE-BE $p=0.7467$ \\
\hline \multirow{2}{*}{ Age } & $60-74(\mathrm{~A})$ & 164 & 76.64 & 50 & 23.36 & 50 & 41.67 & 70 & 58.33 & AC-AE $p=0.0000$ & AC-BC $p=0.0192$ \\
\hline & 75-84 (B) & 17 & 56.67 & 13 & 43.33 & 4 & 25.00 & 12 & 75.00 & BC-BE $p=0.0400$ & AE-BE $p=0.2005$ \\
\hline \multirow{4}{*}{$\begin{array}{c}\text { Educational } \\
\text { attainment }\end{array}$} & Higher (A) & 54 & 83.10 & 17 & 16.90 & 20 & 66.67 & 10 & 33.33 & $\mathrm{AC}-\mathrm{AE} \mathrm{p}=0.0675$ & AC-GC p $=0.0001$ \\
\hline & Secondary (B) & 114 & 74.51 & 39 & 25.49 & 17 & 45.95 & 20 & 54.05 & BC-BE $p=0.0008$ & BC-GC p $=0.0008$ \\
\hline & Vocational (G) & 5 & 33.33 & 10 & 66.67 & 11 & 37.93 & 18 & 62.07 & GC-GE $p=0.7637$ & $\begin{array}{l}\text { BE-HE } p=0.0030 \\
\text { AE-GE } p=0.0271\end{array}$ \\
\hline & Primary H) & 3 & 60.00 & 2 & 40.00 & 6 & 15.00 & 34 & 85.00 & HC-HE $p=0.0177$ & GE-HE $p=0.0291$ \\
\hline \multirow{6}{*}{$\begin{array}{l}\text { Financial } \\
\text { status }\end{array}$} & Very good (A) & 10 & 76.92 & 3 & 23.08 & 3 & 60.00 & 4 & 40.00 & $\mathrm{AC}-\mathrm{AE} \mathrm{p}=0.4729$ & BC-GC $p=0.0070$ \\
\hline & & & & & & & & & & & BC-HC $p=0.0030$ \\
\hline & Good (B) & 91 & 82.73 & 19 & 17.27 & 29 & 50.00 & 29 & 50.00 & BC-BE $p=0.0000$ & AC-HC p $=0.0317$ \\
\hline & & & & & & & & & & & $\mathrm{AF}_{\mathrm{H}} \mathrm{HF}_{\mathrm{n}}=00384$ \\
\hline & Average (G) & 80 & 67.23 & 39 & 32.77 & 22 & 32.35 & 46 & 67.65 & GC-GE $p=0.0000$ & BE-GE $p=0.0442$ \\
\hline & Low $(\mathrm{H})$ & 0 & 0.00 & 2 & 100 & 0 & 0.00 & 5 & 100 & HC-HE $p=1.0000$ & BE-HE $p=0.0314$ \\
\hline \multirow{2}{*}{$\begin{array}{c}\text { Senior } \\
\text { organization }\end{array}$} & Member (A) & 138 & 84.66 & 25 & 15.34 & 17 & 56.67 & 13 & 43.33 & AC-AE $p=0.0004$ & AC-BC $p=0.0000$ \\
\hline & Not a member (B) & 43 & 53.09 & 38 & 46.91 & 37 & 34.91 & 69 & 65.09 & BC-BE $p=0.0128$ & AE-BE $p=0.0315$ \\
\hline \multirow{2}{*}{ Marital status } & Married (A) & 90 & 70.87 & 37 & 29.13 & 42 & 40.38 & 62 & 59.62 & AC-AE $p=0.0000$ & AC-BC $p=0.2179$ \\
\hline & Unmarried (B) & 91 & 77.78 & 26 & 22.22 & 12 & 37.50 & 20 & 62.50 & BC-BE $p=0.0000$ & AE-BE $\mathrm{p}=0.7709$ \\
\hline \multirow{2}{*}{$\begin{array}{c}\text { Professional } \\
\text { activity }\end{array}$} & Active (A) & 15 & 65.22 & 8 & 34.78 & 10 & 38.46 & 16 & 61.54 & $\mathrm{AC}-\mathrm{AE} \mathrm{p}=0.0615$ & $\mathrm{AC}-\mathrm{BC} \mathrm{p}=0.3024$ \\
\hline & Not active (B) & 166 & 75.11 & 55 & 24.89 & 44 & 40.00 & 66 & 60.00 & $A D-A F p=0.0000$ & AE-BE $p=0.8852$ \\
\hline
\end{tabular}

Notes: - $(p)$ - probability that the calculated chi-square value will be exceeded, significant differences are marked in bold. Only statistically significant differences are indicated for educational attainment, financial status, and membership in senior organizations (first column to the right).

Source: own study.

No significant differences in the level of tourist activity were observed among university graduates $(\mathrm{p}=0.0675)$ and respondents with vocational education $(\mathrm{p}=0.7637)$, regardless of their place of residence. Respondents with higher education were the most traveled group, whereas respondents with vocational education were the least traveled group in both urban and rural areas. Statistically significant differences were noted among respondents with secondary and primary school education $(\mathrm{p}=0.0008$ and $\mathrm{p}=0.0177$, respectively). In the group of seniors residing in urban areas, university and secondary school graduates traveled more than rural residents with vocational education ( $\mathrm{p}=0.0001$ and $\mathrm{p}=0.0008$, respectively). In the group of rural residents, respondents with secondary education were more likely to travel for leisure than subjects with primary education $(\mathrm{p}=0.0030)$, whereas respondents with higher education were characterized by a higher propensity for travel than subjects with vocational $(\mathrm{p}=0.0271)$ and primary education $(\mathrm{p}=0.0291)$.

An analysis of relationships between the tourist behavior of respondents and their financial standing revealed that only persons with the lowest material status, both urban and rural residents, refrained from all types of tourist activity (100\%). In urban areas, respondents from the remaining income groups participated in some form of tourism. In rural areas, the number of active travelers decreased with a decline in their self- 
perceived economic security. Urban residents with a good and average financial status traveled significantly more often than rural residents from the corresponding income groups ( $\mathrm{p}=0.0000$ in both cases). The number of active tourists was higher in the group of subjects enjoying a very high financial standing in both urban and rural areas $(\mathrm{p}=0.4729)$. City dwellers with high incomes were more likely to become involved in tourist activities than those with an average $(\mathrm{p}=0.0070)$ and low $(\mathrm{p}=0.0030)$ financial status. Persons with a very good and average financial standing were significantly more likely to travel than those with a low material status $(\mathrm{p}=0.0317$ and $\mathrm{p}=0.0464$, respectively). Rural residents with a very good and good financial status were more frequent travelers than subjects with a low $(\mathrm{p}=0.0384$ and $\mathrm{p}=0.0314)$ and average status (good financial status: $\mathrm{p}=0.0442$ ).

Urban residents who were and were not members of senior organizations were characterized by significantly higher travel propensity than their rural counterparts ( $\mathrm{p}=0.0004$ and $\mathrm{p}=0.0128$, respectively). In both urban and rural areas, members of senior organizations were significantly more active than persons who were not affiliated with such organizations ( $\mathrm{p}=0.0000$ and $\mathrm{p}=0.0351$, respectively).

Married and unmarried subjects residing in urban areas were significantly more likely to travel than rural residents ( $\mathrm{p}=0.0000$ in both cases). No significant differences in tourist behavior were observed between married and unmarried residents in rural or urban areas. Professionally active seniors from rural and urban areas did not differ significantly in their travel propensity, whereas urban residents who were not professionally active were significantly more likely to travel than their rural counterparts $(p=0.0000)$. No significant differences in tourist activity were observed between professionally active and inactive seniors residing in rural and urban areas.

\section{Discussion}

The majority of the surveyed respondents $(61.84 \%)$ were engaged in some form of tourist activity. Research into the tourist behavior of Polish consumers indicates, however, that seniors account for the smallest group of clients participating in any form of tourist activity (Bąk, 2012a). Relatively low levels of tourist activity were also reported among seniors in Israel (Fleischer, \& Pizam, 2002). Contemporary seniors are in better health, have more leisure time, and take greater interest in travel than their predecessors. Many seniors continue to be active, enjoy flexible schedules, take frequent and longer holidays, and spend more on leisure activities than youths (Baloglu, \& Shoemaker 2001; Huang, \& Tsai, 2003). Similar conclusions can be drawn from our study of seniors residing in the region of Warmia and Mazury. According to the Swiss Travel Market, seniors aged 65 years and over have a net travel propensity of 82\% (Bieger, \& Leasser 2002). In studies analyzing tourism demand in Germany, the net travel propensity of seniors aged 60 to 69 years was estimated at $76 \%$, while for seniors over 70, it was $63 \%$ (Lohmann, Aderhold, \& Zahla, 2004). Similar results were reported by Hopflinger (2005). The net travel propensity of seniors is somewhat lower in the USA (Collia, Sharpe, \& Giesbracht, 2003) and Australia (Horneman, Carter, Wie, \& Roys, 2002). Consumers from the 55+ group were responsible for $80 \%$ of the total vacation spending in the United States (Insurance Institute for Highway Safety, 2001; Shoemaker, 1989).

In this study, the vast majority of respondents who participated in tourist activities resided in urban areas. Most rural residents (60.29\%) did not travel. A statistical analysis revealed significant differences between urban and rural residents, and the distribution of respondents differed in each group. Similar results were reported in a study commissioned by the Polish Ministry of Sport and Tourism (PMS\&T, 2012). According to the Central Statistical Office (GUS), only around 30\% of rural seniors travel for leisure. Urban residents, on the other hand, were the most highly traveled group of elderly citizens (Bąk, 2012b). Those results indicate that place of residence is a criterion that significantly influences the travel propensity of seniors and that elderly rural residents are significantly less likely to travel than their urban counterparts. The research data suggest that rural residents are generally far less likely to travel for leisure than urban residents in Poland (Stasiak, 2011). Those differences can be attributed to various factors. The primary reason is that rural residents who are employed in agriculture cannot travel frequently due to the nature of their work. Their access to travel 
agents or other outlets offering tourist services is also much more limited than in urban areas. According to Rosenbloom, means of transport are not adapted to senior needs in rural areas (Rosenblum, 2001). Belza et al. (2004), King et al. (2003), Giuliano (2004), and Ritter and Straight (2002) demonstrated that walking tours for seniors are more accessible in urban areas due to the greater availability of marked trails and paths, which are often unavailable in rural destinations.

The vast majority of the surveyed respondents were female. This is consistent with expectations, as women outnumber men in Poland. The disproportion between the sexes is particularly high among seniors because women enjoy relatively longer life expectancy than men (Polish Central Statistical Office, 2012). The above also applies to the region of Warmia and Mazury (Nowicka, 2012). The discussed trend is observed in many regions of the world. In 2013, according to the United Nations Department of Economic and Social Affairs, there were 85 men per 100 women in the 60+ group, and 61 men per 100 women in the $80+$ group (United Nations, 2013). In the present study, senior citizens residing in urban areas were significantly more likely to travel than their rural counterparts, but gender did not influence the travel propensity of the examined groups (separately for urban and rural residents). Other studies investigating the Polish tourist market revealed that gender is not a determinant of travel propensity among seniors of other age groups (Bąk 2012a). In the tourist sector, gender could influence motivation for travel (Boksberger \& Laesser 2008; Jang \& Wu 2006) or choice of tourist activity, but further studies of Polish seniors are required to test this hypothesis. Elderly Americans are more likely to travel by car than any other means of transport, and nearly 9 out of 10 trips taken by seniors involve a personal vehicle. In most vehicle trips, the passenger seat is more likely to be occupied by a woman than a man. During a road trip, women aged $75+$ are two and a half times more likely to be passengers than men from the same age group, and the vast majority of those trips involve a passenger car rather than a van or an SUV. Upon entering retirement, women have less driving experience than men (Rosenbloom, 2006). Hu, J. Wang, and L. Wang (2013) demonstrated that travel rates differ between men and women and that women travel less than males. Huang and Tsai (2003) arrived at the opposite conclusions.

An analysis of gender differences in tourist behavior revealed that women $(75.7 \%)$ and men $(63.33 \%)$ residing in urban areas had a significantly higher propensity to travel than their urban counterparts (women: 40.66\%; men: $37.78 \%$ ). No such relationships were noted in either of the studied groups in an analysis of the effects of gender on tourist activity, done separately for urban and rural areas

Age is often regarded as one of the key determinants of tourist behavior, as is demonstrated by a Swedish study (Boksberger, \& Laesser, 2008). Hu et al. (2013) demonstrated that daily trip frequency decreases with age in women, whereas the relevant decrease in males was not significant. In this study, the surveyed respondents formed a relatively homogeneous age group: they were 60 years old and older. In the group of urban residents, the percentage of seniors participating in tourist activities decreased significantly with age. This decrease was particularly visible in the $80+$ group, and similar findings have been reported by other authors (Bąk, 2012a, 2012b). Those differences can be attributed to the deteriorating physical and mental abilities of the elderly, which indicates that the travel propensity of seniors is more likely to be limited by physical factors related to age and health than in other groups (Grzelak-Kostulska et al., 2011). In the group of rural respondents, age was not a key determinant of travel propensity. Rural residents were far less active tourists than seniors residing in urban areas, and the reasons for that probably extend far beyond the basic determinants of tourist behavior.

Educational attainment is yet another factor that influences travel propensity. Surveys of tourist behavior conducted in Poland (Polish Central Statistical Office, 2012) revealed that people with university and secondary education were the most frequent travelers. Educated consumers are more ambitious, pursue higher standards of living (of which tourism is a part), have more developed higher-order needs, and generally enjoy a higher financial status. The results of our study confirm that travel propensity increases with educational attainment, but differences were observed between urban and rural residents with respect to this factor. In both groups, university graduates were the most active tourists, which is consistent with the general trend in the tourist sector (Boksberger, \& Laesser, 2008). In the group of urban residents, seniors with vocational education were the most reluctant to travel. In rural areas, only university graduates were, in most cases, active tourists. 
Educational attainment was significantly lower in rural than in urban areas, and the vast majority of the surveyed rural residents had a primary-level education. It seems that persons with low educational attainment often have little interest in physical activity, including tourism. Seniors who reside in rural areas confirm this hypothesis.

In the literature, financial standing is often cited as an important determinant of travel propensity. In numerous empirical studies, respondents often pointed to financial problems as the key obstacle to travel (Nyaupane, \& Andereck, 2008). This trend is also observed among seniors (Bąk 2012a; Son, Mowen \& Kerstetter, 2008), and there is evidence to suggest that financial barriers are the main reason preventing seniors from traveling for pleasure (Fleischer, \& Pizam, 2002). Huang and Tsai (2003) demonstrated that retirement for one year is a more significant factor than full-time employment. Personal savings were regarded as a more important source of income than pensions, followed by social benefits and donations from family and friends. In this study, only seniors who described their financial status as low were reluctant to travel at all, and this was true of both urban and rural residents. It should be noted, however, that only $1.84 \%$ of all respondents belonged to this category. In general, the surveyed subjects enjoyed a similar standard of living in both rural and urban areas. Yet the majority of urban respondents took up some form of tourist activity regardless of their financial status, whereas the number of active tourists decreased with income in rural areas. Therefore, the travel propensity of seniors residing in urban areas was not related with their material situation, whereas the tourist behavior of rural residents was linked with their financial status. The results noted in the group of urban residents seem to suggest that the rural residents' reluctance to travel is not entirely motivated by financial concerns. Rural residents may not have developed an innate need to travel. The fact that urban residents with similar incomes can afford to travel would suggest that rural dwellers could also afford to embark upon this type of leisure activity. Clearly, tourism is simply not a leisure option that is budgeted for by rural residents.

The quality of life of senior citizens is a topic that is garnering more attention from researchers and governments in Poland and other countries around the world. Various programs dedicated to seniors have been launched, including tourist promotion programs such as Calypso or Europe Senior Tourism. Universities of the Third Age are very popular in Poland, and they promote positive attitudes towards tourism among seniors by organizing various excursions and trips at a very low cost (Omelan, Romanowska, \& Skrzypczak, 2013). Seniors who are members of such organizations have better and cheaper access to tourist activities that are adapted to their physical and mental abilities. In this study, more than half of the respondents were members of senior organizations, in particular in urban areas where $66.80 \%$ of the subjects belonged to such organizations. In rural areas, such initiatives were far less popular $(22.06 \%$ members). In both urban and rural areas, members of senior organizations were significantly more likely to travel. Among the members of senior organizations, the number of active tourists was significantly higher in urban than in rural areas. Perhaps rural organizations promote types of rural activities other than tourism. In this study, membership in senior organizations largely influenced seniors' propensity for travel. It should also be noted that senior organizations are found mostly in cities, and rural residents are not always able to join. Despite the above, rural dwellers' reluctance to participate in such initiatives could also result from a lack of interest in such organizations and in leisure activities.

In this study, $60.79 \%$ of the respondents were married, and the percentage of married respondents was significantly higher in rural than in urban areas. This difference could be explained by sociological or psychological research, which was not a part of this study. Marital status did not influence the travel behavior of seniors within each group (urban and rural residents). Both married and unmarried urban residents were significantly more likely to travel than their rural counterparts. In spite of this, marital status does not seem to be related with travel propensity among senior citizens.

In Poland, the retirement age was increased by new regulations that came into force on January 1, 2013. In the previous system, early retirement was possible by the age of 50. In this study, all respondents were 60 and older, and the majority (87.11\%) were retired. The percentage of professionally active respondents was significantly higher in rural than in urban areas. However, professional activity had no significant effect on 
tourist behavior. A comparison of retired and professionally active respondents revealed that retired urban residents are significantly more likely to travel for leisure than retired rural dwellers. This difference could probably be attributed to the fact that rural residents are generally far less likely to participate in tourist activities regardless of their retirement status.

Polish researchers analyzing the travel choices of retired citizens often observe that Polish seniors are characterized by relatively low levels of tourism consumption in comparison with seniors in Western Europe and the US (Śniadek, 2007). This view is not fully supported by the results of this study as, on the whole, the surveyed respondents had a high interest in travel for leisure. Considerable differences were noted when respondents' place of residence was taken into account: urban residents were active tourists, while rural residents were reluctant travelers. Place of residence seems to be an important criterion influencing the tourist behavior of seniors. Interestingly, factors such as gender, professional activity, and marital status were unrelated to the travel propensity of seniors from different groups (urban and rural residents), but they were found to be significant when rural residents were compared with urban dwellers. This proves that place of residence is a key determinant of tourist behavior in the 60+ group.

The only traits shared by the analyzed groups were age and similar financial status. Rural residents, who are generally characterized by low travel propensity, are an interesting group. Rural dwellers who have an interest in travel are similar to seniors residing in cities: they are well educated, enjoy a good financial standing, and belong to senior organizations. They can be regarded as members of a "rural intellectual elite", a group that brings together teachers, doctors, clergy, and people who moved to the countryside upon retirement but did not change their urban habits. The remaining rural residents are visibly different from the above group. For this reason, the described group of seniors constitutes a particularly interesting object of sociological research, not only in view of their tourist behavior, but also in reference to their specific lifestyle choices. The question arises as to why seniors residing in the Polish countryside could be regarded as a discriminated social group whose rights to leisure and travel are seriously compromised (Stasiak, 2011). The low organizational standards, poor access to information, low levels of social capital, and insufficient infrastructure development in Polish rural areas lend some credence to this hypothesis. As a result, elderly people living in the countryside show no interest in tourism and are characterized by low levels of social and organizational activity. However, the problem seems to be rooted in the absence of lifelong habits related to the pursuit of leisure outside one's place of residence, which is closely related with employment in agriculture as well as the low educational attainment of rural residents. Propensity for travel is also shaped by the attitudes and opinions of the local community, including family, school, and social organizations (Krzymowska-Kostrowicka, 1997). In this study, the surveyed rural residents clearly grew up in communities where tourism was not recognized as a worthwhile pastime. Rural dwellers also have few opportunities for joining senior clubs, which operate mostly in urban areas. Activists and decision makers responsible for senior programs should turn their attention to rural areas to ensure that local residents can take full advantage of travel opportunities. Younger generations of rural residents should also be targeted by lifestyle campaigns promoting a more proactive approach to life and leisure. As a result, rural dwellers will undoubtedly enjoy better physical and mental health in their autumn years.

\section{Limitations}

This study surveyed seniors residing in only one of Poland's 16 administrative regions (provinces/voivodships). For the evaluated relationships to be investigated in greater depth, similar studies should be carried out in other parts of the country, including in communities inhabiting mountainous regions or coastal areas (Pomerania), and in other regions of the world where tourism and agriculture are the main sources of income. 


\section{Conclusions}

The results of this study point to differences in the travel propensity of seniors (60+) residing in rural and urban areas of the region of Warmia and Mazury in Poland. Urban dwellers are more avid tourists, whereas rural residents are far less likely to travel for leisure. Factors such as gender, professional activity, and marital status are not related with the travel propensity of seniors from different groups (urban and rural residents), but they become significant when rural residents are compared with urban dwellers. Age is an important determinant only in urban areas, where the travel propensity of seniors decreases with age. The financial status of respondents is related with tourist behavior only in rural areas, where seniors from lower income groups are less likely to travel. Educational attainment and membership in senior organizations significantly affects the level of tourist activity. Our findings indicate that place of residence is the key determinant of the travel behavior of seniors from the region of Warmia and Mazury.

\section{REFERENCES}

Bąk, I. (2012a). Zastosowanie wybranych metod statystyczno-ekonomicznych w badaniu aktywności turystycznej seniorów w Polsce /The use of selected statistical and economic methods in the analysis of the tourist activity of senior citizens in Poland/. Przeglad Statystyczny, 2, 313-332.

Bąk, I. (2012b). Wpływ wybranych czynników na zróżnicowanie uczestnictwa w wyjazdach turystycznych na przykładzie gospodarstw domowych emerytów /The influence of selected factors on tourist behavior on the example of senior households/. Zeszyty Naukowe Uniwersytetu Szczecińskiego, 697, 225-241.

Baloglu, S., \& Shoemaker, S. (2001). Prediction of seniors travelers' motorcoach use from demographic, physiological, and psychographic characteristics. Journal of Travel Research, 40(1), 12-18.

Bański, J. (2014). Structure and ownership of agricultural land in Poland in the first years of new millennium. Journal of Agricultural Science and Technology, B(4), 85-93.

Bański, J., \& Wesołowska, M. (2012). Architectural transformations of residential buildings in rural areas of the Lublin region. Architectonica, 2, 174-186.

Belza, B., Walwick, J., Shiu-Thornton, S., Schwartz, S., Taylor, M., \& LoGerfo, J. (2004). Older adult perspectives on physical activity and exercise: Voices from multiple cultures. Preventing Chronic Disease, 1(4), 1-12.

Benova, L., Grundy, E., \& Ploubidis, B. (2014). Socioeconomic position and health-seeking behavior for hearing loss among older adults in England. Journal of Gerontology, 70(3), 443-452. doi: 10.1093/geronb/gbu024.

Bieger, T., \& Laesser, C. (2002). Market segmentation by motivation: The case of Switzerland. Journal of Travel Research, 34(1), 33-39.

Blazey, M.A. (1987). The differences between participants and nonparticipants in a senior travel program. Journal of Travel Research, 25(1), 7-12.

Boksberger, P.E., \& Laesser, C. (2008). Segmenting the senior travel market by means of travel motivation - Insights from a mature market (Switzerland) (pp. 1-13). CAUTHE Council of Australian University Tourism and Hospitality Education. Gold Coast: Griffith University.

Bunda, M., \& Walewski, P. (2012). Starość: problem młodych /Old age: a problem of the young/. POLITYKA, 2872, 2427.

Cha, S., Mccleary, K.W., \& Uysal, M. (1995). Travel motivations of Japanese overseas travelers: A factor-cluster segmentation approach. Journal of Travel Research, 34(1), 33-39.

Chesworth, N. (2006). The baby boom generation and leisure and travel in the future. In K. Weiermair, H. Pechlaner, \& T. Bieger (Eds.), Time shift, leisure and tourism. Impacts of time allocation on successful products and services (pp. 2332). Berlin: ESV.

Collia, D.V., Sharpe, J., \& Giesbrecht, L. (2003). The 2001 National Household Travel Survey: A look into the travel patterns of older Americans. Journal of Safety Research, 34, 461-470.

Dann, G. (1981). Tourist motivation: An appraisal. Annals of Tourism Research, 8, 184-219.

Esichaikul, R. (2012). Travel motivation, behavior and requirements of European senior tourists to Thailand. PASOS. Revista de Turismo y Patrimonio Cultural, 10(2), 47-58. 
Fleischer, A., \& Pizam, A. (2002). Tourism constraints among Israel seniors. Annals of Tourism Research, 29(1), 106123.

Freund, A.M., \& Smith, J. (1997). Self-definition in old age. Zeitschrift fur Sozialpsychologie, 28(1-2), 44-59.

Giuliano, G (2004). Land use and travel patterns among the elderly. In Transportation in an Aging Society: Decade of Experience. Technical Papers and Reports from a Conference, November 7-9, 1999. Bethesda, Maryland: TRB Press.

Gokovani, U., Bahar, O., \& Kozak, M. (2007). Determinants of length of stay: A practical use of survival analysis. Tourism Management, 28(3), 736-746.

Gołdys, A., Krzyżanowska, Ł., Ostrowski, Ł., \& Stec, M. (2012). ZOOM na Uniwersytety Trzeciego Wieku - raport z badań /A closer look at Universities of the Third Age/. Warszawa: Towarzystwo Inicjatyw Twórczych „Ę” Press.

Gorman, M. (1999). Development and the rights of older people. In J. Randel et al. (Eds.), The Ageing and Development Report: Poverty, Independence and the World's Older People (pp. 3-12). London: Earthscan Publications Ltd.

Grzelak-Kostulska, E., Hołowiecka, B., \& Kwiatkowski, G. (2011). Problemy aktywności turystycznej seniorów /Problems related to the tourist activity of senior citizens/. In A. Stasiak (Ed.), Perspektywy i kierunku rozwoju turystyki społecznej w Polsce /Prospects and trends in social tourism development in Poland/ (pp. 266-279). Łódź: WSTiH Press.

Hawkins, B.A., Peng, J., Hsieh, C.-M., \& Eklund, S.J. (1999). Leisure constraints: A replication and extension of construct development. Leisure Sciences, 21(3), 179-192.

Henwood, T.R., Riek, S., \& Taaffe, D.R. (2008). Strength versus muscle power-specific resistance training in communitydwelling older adults. Journal of Gerontology Series A: Biological Sciences \& Medical Sciences, 63, 83-91.

Höpflinger, F. (2005). Alternde Gesellschaft - Verjüngte Senioren / Aging Society - Rejuvenated Seniors/. Zurich: Neue Zürcher Zeitung.

Horneman, L., Carter, R.W., Wie, S., \& Roys, H. (2002). Profiling the senior traveler: An Australian perspective. Journal of Travel Research, 41(1), 23-37.

Hu, X., Wang, J., \& Wang, L., (2013). Understanding the travel behavior of elderly people in the developing country: A case study of Changchun, China. Procedia - Social and Behavioral Sciences, 96, 873-880.

Huang, L., \& Tsai, H.-T. (2003). The study of senior traveler behavior in Taiwan. Tourism Management, 24, 61-574.

Insurance Institute for Highway Safety (2001). Older drivers up close: They aren't dangerous except maybe to themselves. Insurance Highway Safety Status Report, 36(8), 1-8.

Jang, S.C., Bai, B., Hong, G.-S., \& O’Leary, J.T. (2004). Understanding travel expenditure patterns: A study of Japanese pleasure travelers to the United States by income level. Tourism Management, 25(3), 331-341.

Jang, S.C., \& Wu, C.-M.E. (2006). Seniors' travel motivation and the influential factors: An examination of Taiwanese seniors. Tourism Management, 27, 306-316.

Kazemina, A., Del Chiappa, G., \& Jafari, J. (2015). Seniors' travel constraints and their coping strategies. Journal of Travel Research, 54(1), 80-93.

King, W.C., Brach, J.S., Belle, S., Killingsworth, R., Fenton, M., \& Kriska, A. (2003). The relationship between convenience of destinations and walking levels in older women. American Journal of Health Promotion, 18(1), 74-82.

Kinsella, K., \& Velkoff, V. A. (2001). An Aging World: 2001. Series P95/01-1. Washington DC: U.S. Census Bureau.

Krzymowska-Kostrowicka, A. (1997). Geoekologia turystyki i wypoczynku /Geoecology of tourism and recreation/. Warszawa: PWN.

Lohmann, M., Aderhold, P., \& Zahla, B. (2004). Urlaubsreisetrends 2015: Die RA-Trendstudie - Entwicklung der Touristischen Nachfrage der Deutschen /Trends in travel and tourism 2015: Trends analysis - tourism demand development in Germany/. Kiel: Forschungsgemeinschaft Urlaub und Reisen e.V.

Mroczek, D.K., \& Kolarz, C.M. (1998). The effect of age on positive and negative affect: A developmental perspective on happiness. Journal of Personality and Social Psychology, 75(5), 1333-1349.

Nickerson, N.P. (2000). Travel and recreation outlook 2000: Focusing on demographics. Montana Business Quarterly, $38(1), 23$.

Nicolau, J.L., \& Más, F.J. (2005). Stochastic modeling: A three-stage tourist choice process. Annals of Tourism Research, 32(1), 49-69. 
Nowicka, A. (2012) Raport dotyczący udziału seniorów w życiu publicznym województwa warmińsko-mazurskiego /Report on senior citizens' participation in public life in the region of Warmia and Mazury/. Olsztyn: MP\&PS Press.

Nyaupane, G.P., \& Andereck, K.L. (2008). Understanding travel constraints: Application and extension of a leisure constraints model. Journal of Travel Research, 49(1), 39-45.

Omelan, A., Romanowska, A., \& Skrzypczak, A. (2013). Aktywność turystyczna słuchaczy Warmińsko-Mazurskiego Uniwersytetu Trzeciego Wieku /Tourist activity of students of the Warmia and Mazury University of the Third Age/. In A. Kasprzyk, \& P. Maciaszczyk (Eds.), Turystyka i rekreacja a przedsiębiorczość /Tourism and recreation versus enterprise/ (pp. 267-279). Tarnobrzeg: PWSZ Press.

Patterson, I.R. (2006). Growing Older: Tourism and Leisure Behavior of Older Adults. Wallingford/ Cambridge: CABI Publishing.

Polish Central Statistical Office (2012). Wyniki Narodowego Spisu Powszechnego Ludności i Mieszkań 2011. Podstawowe informacje o sytuacji demograficzno-społecznej ludności Polski oraz zasobach mieszkaniowych /National Population Census 2011. Basic data on the demographic and social status of Polish residents and housing resources in Poland/. Warszawa: GUS.

Polish Ministry of Sport and Tourism (PMS\&T) (2011). Preferencje osób starszych dotyczące wyjazdów turystycznych /Tourist preferences of senior citizens/. Wrocław: PMS\&T Press.

Polish Social Insurance Institution, Department of Statistics and Actuarial Forecast (2012). Structure of Old-Age and Disability Pensions After Indexation in March 2012. Warszawa: ZUS.

Rabiej, M. (2012). Statystyka z programem Statistica /Statistics with the Statistica program/. Gliwice: Helion S.A. Press.

Reece, W.S. (2004). Are senior leisure travelers different? Journal of Travel Research, 43(1), 11-18.

Ritter, A.S., Straight A., \& Evans, E. (2002). Understanding Senior Transportation: Report and Analysis of a Survey of Consumers Age 50+. Washington, DC 20049, AARP Public Policy Institute.

Roebuck, J. (1979). When does old age begin?: The evolution of the English definition. Journal of Social History, 12(3), 416-428.

Romsa, G., \& Blenman, M. (1989). Vacation patterns of the elderly German. Annals of Tourism Research, 16, 178-188.

Rosenbloom, S. (2006). Understanding women's and men's travel patterns: The research challenge. In Transportation Research Board 2006 Executive Committee (Eds.), Transportation Research Board Conference Proceedings 35. Research on Women's Issues in Transportation (pp. 7-21). Washington, DC.: Transportation Research Board of the National Academies.

Rosenbloom, S., \& Waldorf, B. (2001). Older travelers: Does place or race make a difference? In Personal Travel: The Long and the Short of It. Conference Proceedings, Transportation Research Board, June 29-July 1, 1999 (pp. 103-120).

Rosenbloom, S. (2001). Sustainability and automobility among the elderly: An international assessment. Transportation, 28, 375-408.

Sauran, A. (1978). Economic determinants of tourist demand: A survey. The Tourist Review, 33(1), 2-4.

Shankar, A., McMunn, A., \& Steptoe, A. (2010). Health-related behaviors in older adults. Relationships with socioeconomic status. American Journal of Preventive Medicine, 38(1), 39-46.

Shoemaker, S. (1989). Segmentation of the senior pleasure travel market. Journal of Travel Research, 27(3), 14-21.

Śniadek, J. (2007). Konsumpcja turystyczna polskich seniorów na tle globalnych tendencji w turystyce /Tourist consumption of Polish seniors in comparison with global trends/. Gerontologia Polska, 15(1-2), 21-30.

Son, J.S., Mowen, A.J., \& Kerstetter, D.L. (2008). Testing alternative leisure constraints negotiation models: An extension of Hubbard and Mannel's study. Leisure Sciences, 30(3), 198-216.

Stasiak, A. (2011). Wieś jako obszar turystyki społecznej/The countryside as an area of social tourism/. Folia Pomeranae Universitatis Technologiae Stetinensis, Oeconomica, 288(64), 19-32.

Straight, C.R., Dorfman, L.R., Cottell, K.E., Krol, J.M., Lofgren, I.E., \& Delmonico, M.J. (2012). Effects of resistance training and dietary changes on physical function and body composition in overweight and obese older adults. Journal of Physical Activity and Health, 9, 875-883.

Szmigin, I., \& Carrigan, M. (2000). The older consumer as innovator. Does cognitive age hold the key? Journal of Marketing Management, 16, 505-527. 
Thane, P. (1989). History and the sociology of ageing. Social History of Medicine, 2(1), 93-96.

United Nations (UN) (2013). Department of Economic and Social Affairs, Population Division (2013). World Population Ageing 2013. ST/ESA/SER.A/348. New York: United Nations.

Watt, H.C., Carson, C., Lawron, D.A., Patel, R., \& Ebrahim, S. (2009). Influence of life course socioeconomic position on older women's health behaviors: Findings from the British women's heart and health study. American Journal of Public Health, 99(2), 320-327. doi: 10.2105/AJPH.2007.129288.

World Health Organization (WHO) (2015). Definition of an Older or Elderly Person. Proposed Working Definition of an Older Person in Africa for the MDS Project. Retrieved May 25, 2015, from http://www.who.int/healthinfo/survey/ageingdefnolder/en/

Yasamy, M.T., Dua, T., Harper, M., \& Saxena, S. (2015). Mental Health of Older Adults, Addressing a Growing Concern. Geneve: World Health Organization, Department of Mental Health and Substance Abuse. Retrieved May 25, 2015, from www.who.into/mental_health/world-mental-health-day/WHO_paper_wmhd_2013.pdf

AUTHOR'S ADDRESS: $\quad$ Robert Podstawski

Department of Physical Education and Sport

University of Warmia and Mazury in Olsztyn

Prawocheńskiego 7

10-720 Olsztyn, Poland

E-mail: podstawskirobert@gmail.com

Received: 20 March 2016; Accepted: 10 June 2016 